\title{
Freudian Psychoanalysis of the Character of Graham Hendrick in Julian Barnes' Before She Met Me
}

Bhoomi M. Gurjar

Assistant Professor

Department of English

Government Arts College

Shahera, Panchmahal, Gujarat, India

bhoomigurjar1994@gmail.com

Abstract

This research paper tries to analyze Graham Hendrick's personality who suffers from serious delusional jealousy in Julian Barnes's Before She Met ME. The areas which are covered in this study are: the character type of Graham Hendrick, the situations and circumstances, which he faces and the psychological problems that arise in him because of the clash between his personality and situations. In this paper, the researcher has analyzed the character of Graham by applying Freudian psychoanalytic theories.

Keywords: Psychoanalysis, Paranoia, Transference.

Psychoanalysis in literature always attracts the readers and reveals new meanings about the text. While analyzing a text from a psychoanalytical point of view, it becomes necessary to read not only what the author wants to say through the text but what the text itself suggests. The function of psychoanalytic literary criticism is to read between the gap of words and sentences. Psychoanalysis had a great impact on modern literature. Basic Freudian concepts like slip of the tongue, transference, memory of errors, delusion, dreams, etc. are 
used as tools and techniques by modern writers. With the help of these techniques, a writer takes the reader into the journey of characters' inner personalities and unconscious thoughts. Julian Barnes is also such a modern British writer who takes help of these various Freudian psychoanalytical methods in his writing. Before She Met $M E$ is a novel written by Julian Barnes in 1982. It is a story of a history professor Graham Hendrick, who suffers from various neurological diseases. He comes out as a pathetic figure who himself is the cause of his pain and ultimate doom. A novel can be looked upon from various psychoanalytical perspectives and different theories can be applied to different characters. Graham Hendrick is a protagonist of the novel and his character deserves much psychoanalytical interpretation.

In the novel, Before She Met Me, Graham Hendrick is a professor who transfers his attitude to his girl students. He uses the defence mechanism whereby he reacts aggressively to sexuality in girls because he is not satisfied with his own sexual life. While inwardly he hides his real motives. To satisfy his ego, he punishes those girls who cross their legs while sitting by giving them difficult subjects for essay-writing. It can be seen as Graham cannot express his sexuality openly because of his age and stature and so envies those young girl students. Graham's inner feelings for those girl students come out in his interaction with his wife. When Barbara demands to know the name of his mistress, he immediately explains to her in defence:

\section{It's not a student. I'm leaving you. ${ }^{1}$}

It simply means that this thought of an affair with his girl student must have remained somewhere in his mind. But Graham finds it ridiculous to have an affair with a student and it sounds incestuous to him. And this thought, which has been pushed into the unconscious, comes to the fore when he does not know what to speak to his wife. So, this fury or one can say the state of anxiety reveals Graham's repressed thoughts. Graham's habit of transference 
can be seen again as he wonders whether his male students can commit adultery with his wife.

After getting divorced from Barbara and getting married to Ann, Graham should feel satisfied. He feels happy with Ann but does not feel as if he is really married even after the marriage. It is perhaps because he still feels guilty for leaving his first wife. He does not feel married because there is a difference between his two marriages. The first marriage was a conventional one where they started their life after the wedding, whereas in the second one there does not remain any curiosity as their love life has already started even before the marriage.

Graham himself feels inferior and unsuitable to Ann. He cannot cope up with that idea that a man like him can have a beautiful wife. And, so he tries to be more possessive for Ann. He starts thinking about all those years that Ann has not spent with him. Graham suffers from an obsessive jealousy because he himself is an unreliable person. He was attracted towards Ann while being committed to Barbara in marriage. So he projects his own feelings in Ann. Graham himself feels guilty and so he wants to see Ann guilty.

Graham's resentment for having failed in performing the duties of a husband and father affects his relationship with Ann. He has betrayed Barbara in their marriage, so he transfers his own image to Ann and suspects her for being unfaithful to him. In Freudian term, Graham suffers from 'paranoia', that is here a delusion of jealousy. There is no valid reason for being jealous, but still Graham feels the jealousy. Paranoia is a chronic coherent madness. Graham also develops this jealousy gradually which leads him to complete insanity. It is because of his obsessive jealousy that Graham goes again and again to the theatre to watch the same movie of Ann. He cannot help it and it becomes a compulsion for him to go there again and again. Paranoia can be a defence mechanism against homosexual thoughts. 
Its' glimpses can be seen when Graham talks about homosexuality of the $13^{\text {th }}$ century priests. He talks about it very casually whereas Ann feels disgusted to hear about it.

Graham's memory fails in recalling the names of Ann's ex-lovers despite many efforts. Freud says,

If anyone forgets an otherwise familiar proper name, or has difficulty in retaining it in his memory despite all efforts, then the conclusion lies close at hand, that he has something against the bearer of the name and does not like to think of him. ${ }^{2}$

So, in forgetting the memory also, person's unconscious feelings play an important role. As Graham hates knowing the names of Ann's past lovers, his unconscious does not allow those names to reappear in his mind as well as life.

Graham explains that it is only after seeing the film that these thoughts of jealousy and Ann's adultery have started coming into his mind. It does not fit the theory of Sigmund Freud when he says,

It suddenly begun to hurt that Ann had been to bed with them. It suddenly felt like...I don't know - adultery, I suppose. Isn't that silly? ${ }^{3}$

These ideas haven't risen suddenly. They must have been there in his mind. When he had an extra-marital affair with Ann, he must have thought of his relationship as adultery. Thus Ann becomes the adulteress for him. And these ideas derive their force from a movie, where he actually sees Ann with another man. Though it is a movie only, the distance between reel and real life becomes blurred for him.

In panic, Graham starts masturbating. It is his sexual diversion from opposite sex to own sex. According to Freud, 
...a man who contented himself with incomplete sexual gratification, with manual onamism, for instance, would suffer a true neurosis."

So, here this transformation from opposite sex to own sex itself shows that Graham is not happy in his married life and this dissatisfaction leads him to neurosis. One can also trace here the symptoms of homosexuality or narcissism which Freud believes to be a product of auto-eroticism.

In Freudian psychoanalysis, interpretation of dreams is very much vital to understand the unconscious of a human being. Graham also sees a dream that there is Buck, a cowboy, who is a lover of Ann and he talks about his sexual relationship to Graham. When Graham awakes from the dream, he finds his hands fixed between the mattress and the base of the bed. Here the mattress symbolizes Ann and the bed symbolizes the lover of Ann. His sleeping position clearly indicates that he wants to keep away Ann from her lovers and cannot bear their sexual union. He dreams that Buck spits upon his face while actually he finds his face wet with his own spit. So, in that way, each dream has something to do with reality whether it is in present or in a far away past.

Freud allows us to interpret the meanings of many dream symbols. In the next dream, Graham sees that one man calls Ann a carwash girl. And, he explains to Graham that Ann had sex with four men at the same time. This symbolizes Graham's doubt of his wife. He doubts that Ann has continued her relationship with another man while being married to him. That means not literally but symbolically Ann continues her relationship with more than one man at the same time. In this dream, Graham sees three men entering through the door. Here, the number 3 symbolizes male genital and there is only one person Larry Pitter whom he doubts. After awaking from the dream, Graham cannot remember Ann's confession for having Larry Pitter as her ex-lover. Freud says, 
It is very possible, in fact probable, that the dreamer does know what his dream means, but does not know that he knows, and therefore believes he does not know. ${ }^{5}$

Here Graham knows what his dreams want to tell him, but as these unpleasant ideas have gone into his unconscious, he cannot remember them and believes that he does not know about Larry Pitter.

Graham knows that stories always reflect reality. So, he starts reading Jack's latest novels and in one novel he finds himself able to relate the character of Jock with Jack and his beloved Sarah with Ann. Through this novel, he comes to know that the affair between Jack and Ann has never ceased. Freud suggests that the thoughts never die although they can disappear from the conscious for some time. When they continue to exist for a long period, the time comes when that particular thought becomes the ruling motive for action. Graham also goes on living for many years with the thoughts of jealousy and enmity for Ann's ex-lovers. So, when he comes to know the actual affair of Ann with his own friend Jack Lupton, he cannot at all control his emotions and commits the murder of Jack Lupton. It is only this delusional jealousy that compels Graham to murder Jack against his will and also himself.

Thus Julian Barnes' novel can be interpreted from a Freudian context as the main character shows all the symptoms of repressed sexuality, jealousy and homo-eroticism. 


\section{References}

Barnes, Julian. Before She Met Me. London: Vintage Books, 2014.P. 16.

Freud, Sigmund. A General Introduction to Psychoanalysis. Hertfordshire: Wordsworth Editions, 2012. P. 36.

Barnes, Julian. Before She Met Me. London: Vintage Books, 2014. P. 45.

Freud, Sigmund. A General Introduction to Psychoanalysis. Hertfordshire: Wordsworth Editions, 2012. P. 328.

Ibid. P.81. 